\title{
THE DYNAMIC EFFECTS OF GROWTH, FINANCIAL DEVELOPMENT AND TRADE OPENNESS ON TAX REVENUE IN MALAYSIA
}

\author{
Nanthakumar Loganathan* \\ Universiti Teknologi Malaysia \\ Norsiah Ahmad \\ Universiti Sultan Zainal Abidin \\ Thirunaukarasu Subramaniam \\ University of Malaya \\ Roshaiza Taha \\ Universiti Malaysia Terengganu
}

\begin{abstract}
This study explores the effects of domestic financial development, growth and trade openness on tax collection for Malaysia using the ARDL and bootstrap rolling window estimates covering the period 19702017. The empirical results suggest that, the presence of long-run relationship between tax revenue and per capita GDP and short-run relationship between tax collection, economic growth, financial development and trade openness. We found that there is a short-run unidirectional causality running between tax collection, economic growth and financial development. This result suggests that, in the long-run, economic performance and financial development have an adverse effect on tax collection, while trade openness has no significant causality impact on tax collection in Malaysia. Based on the empirical results of the study, the country should pay more attention to enhance the effectiveness of future public expenditure programs and put more emphasiss on dynamic fiscal policy targeting on tax reform and securing new sources of tax revenues to ensure continuous flow of long-term tax revenue coupled with sustainable economic growth, trade and financial performances in up-coming years.
\end{abstract}

Keywords: Economic; Growth; Financial development; Rolling windows; Taxation; Trade openness.

Received: 9 July 2019

Accepted: 30 December 2019

\section{INTRODUCTION}

In general, financial development and trade openness are key contributors to the economic growth for the past several decades and remains crucial in the future economic development plan of Malaysia. Although the favored export orientation strategy is still maintaining its strong position, both import and export orientation strategies were pursued in a parallel approach. In the early

\footnotetext{
* Corresponding author: Azman Hashim International Business School, Universiti Teknologi Malaysia (UTM), 81030 Johor Bahru, Johor, Malaysia. Email: nanthakumar@utm.my
} 
period after its independence, Malaysian government adopted import substitution strategy by imposing tariffs in protecting local industries from foreign competition. In order to generate revenue, import duties were also being imposed in Malaysia, but this was later distorted by an increase in tariff. To show government support over the domestic market and the unfavorable results from import substitution, export-oriented policy was later initiated, and this policy was also in line with many developing countries, which mainly focused on promoting exports. Following this, export sector becomes the main source of economic growth in the Malaysian economy. The excellent performance of export sector contributed to the increase in Malaysian shares of world merchandise trade and this became the cornerstone of Malaysia's economic transformation from a small open economy into a highly open economy since 1980s, focusing on greater trade and financial integration. The trade openness in Malaysia also resulted in an increase in demand for industrial products and Malaysia was classified among the upper middle-income economies in East Asia and Pacific.

The success of trade openness policy in Malaysia has assisted the emergence of financial market. Rank highly in term of financial openness, Malaysia is well known as the most financially open country after the 'Asian Three Little Dragons' namely Hong Kong, Singapore and South Korea. Together with the open policy on trade, financial openness has resulted in the country becoming a choice destination among foreign investors mainly from the United States of America, Singapore and Japan. The trend shows that average FDI in Malaysia is 3.76 as a percentage of GDP since 1970 and the lowest FDI inflow is recorded in 2009 with the global economic meltdown (World Bank, 2018). In line with this, Malaysia's tax policy in the 1980s and 1990s was the main factor encouraging the development of manufacturing industries and with a high momentum to stimulate the FDI inflows from various sources. A policy which offers incentives such as an investment tax allowance, double deduction, tax deduction to promote exports, establishment of Free Trade Zones (FTZ), and just to name a few has contributed to the high inflow of foreign investors. The strong growth in merchandise trade was the backbone of the trade policy to evolve over time. Malaysia's fiscal policy for ease of trade has helped to facilitate in economic development and to preserve the liberal, predictable, and stable multilateral trading system. Table 1 shows the trade as a share of GDP for 'Asian Three Little Dragons', where Malaysia has recorded a decreasing trend in its share from 2006 to 2015.

Table 1: Asian Three Little Dragons and Malaysia Trade Liberalization

\begin{tabular}{lccccccc}
\hline \multirow{2}{*}{ Countries } & \multicolumn{7}{c}{ Trade liberalization as a share of GDP } \\
\cline { 2 - 8 } & $\mathbf{2 0 0 6}$ & $\mathbf{2 0 0 8}$ & $\mathbf{2 0 1 0}$ & $\mathbf{2 0 1 2}$ & $\mathbf{2 0 1 4}$ & $\mathbf{2 0 1 6}$ & $\mathbf{2 0 1 7}$ \\
\hline Hong Kong & 359.21 & 376.66 & 404.77 & 430.57 & 425.98 & 371.71 & 375.09 \\
Singapore & 430.39 & 441.60 & 373.44 & 370.69 & 359.25 & 310.26 & 322.43 \\
South Korea & 73.55 & 99.93 & 95.65 & 109.89 & 95.30 & 77.71 & 80.78 \\
Malaysia & 202.58 & 176.67 & 157.94 & 147.84 & 138.31 & 128.64 & 135.92 \\
\hline \hline
\end{tabular}

Source: World Bank (2018) 


\section{LITERATURE REVIEW}

There are also abundant of literature that uncovered the influence of tax on economic growth. In general, many studies suggested that higher taxes are associated with lower growth (Abdullah and Morley 2014). While, the property taxes, consumption taxes and personal income taxes appear to be positively related to economic growth, and the corporate income taxes provide opposite evidence among the 21 OECD countries (Arnold et al. 2011). Also, the use of environmental taxation in combating the problem of greenhouse gases provides little or no evidence that it would promote sustainable economic growth thus far among the developing countries. A study using EU and OECD dataset by Abdullah and Marley (2014), found that environmental taxes do not seem to have a significant impact on the economic growth. On the similar ground, Choi and Kim (2016) noticed that a capital income tax cut tends to reduce tax revenue on impact, but it increases the tax base and tax revenue in the long run making it the most efficient policy instrument in terms of minimizing fiscal revenue loss.

Barro (1990) has provided early evidence on how the income tax affects growth, where, increases of income taxes tend to boost the economic growth, but the growth becomes slower when the income taxes increase beyond a certain threshold condition. With modification from Barro (1990) framework, Marrero and Novales (2011) later proved that financing additional public investment by using an income tax would disturb the private investment but the action may often enhance the growth rate in the long-term. When several states in the United States raised their tax rates in order to close budget deficiency, Ojede and Yamarik (2012) found evidence that different strategies taken by each state provides different growth implications. By using the pooled mean group, the findings show that both short and long-run economic growth is lowered by property taxes, while sales taxes lowered the long-run growth rate. Atems (2016) proved that, taxes have negative short and long-run spatial spill-over effect on the growth rate. While, Adkisson and Mohammed (2014) found that slight differences in tax structure tend to cause the economic growth in the short-run period and recovery from the recession period where, the tax structure is a share of revenue from various taxes, such as sales, property, individual income and corporate income taxes. Chen et al. (2017) found that capital taxation has drastically different effects in the short run and in the long run, while Durusu-Ciftci et al. (2018) found only consumption tax does have influence on growth performance.

The positive contribution of trade openness on growth are transmitted through the concept of liberalization that exposes the domestic producers to international best practices in terms of knowledge, technology and skills, and further open a channel for employment. In a pioneering contribution, Agbeyegbe et al. (2006) unveiled the nexus between trade openness and tax revenues. The basic arguments are that trade openness coupled with suitable macroeconomic policies can be undertaken in a way that conserves overall revenue generation. Some countries can take advantage in improving economic stability with their strong policy on trade openness (Mahdavi, 2008; Hisali, 2012; Gaalya, 2015). Perhaps, it may also assist the government in policy formulation to shelter the economy from global economic turbulence. Chandran and Munusamy (2009) pointed out that the success of trade openness policy in Malaysia depends on the tax policy formulation, which further spurs the investment. For example, the incentives provided investment tax allowances, double deduction and reinvestment allowance and establishing FTZ shows that, the government's determination to ensure the success of trade openness policy. 
As trade liberalization seems to be the best indication to project the economic growth, it may also distort government revenue if the domestic tax policy is not strengthening (Baunsgaard and Keen, 2010). However, Mujumdar (2004) argues that, the tax revenue will fall with the tariff reduction, as this will distort the government revenue generation in the short run. In addition, only if the industry is a monopoly, the government could use the profit tax to set off the shortfall in tariff revenue. While, Haque and Mukherjee (2005) suggested that, it is advisable for the government to reduce tariffs on the import duty to encourage trade among the imperfect competitive market. According to Baunsgaard and Keen (2010), there are many countries which are still heavily dependent on trade tax revenues and the trade openness shall be hindered. Jha and Gozgor (2019) noted that globalization is generally associated with lower taxation, however there is evidence that countries with high capital-labor ratio tend to face higher taxation condition. Table 2 shows some of the selected literature related to causal effect.

Table 2: Selected Literature on Causal Effect

\begin{tabular}{|c|c|c|c|}
\hline Author(s) & Countries & Estimation period & $\begin{array}{c}\text { Direction of } \\
\text { causalities }\end{array}$ \\
\hline \multicolumn{4}{|l|}{ Taxation and growth } \\
\hline Arnold et al. (2011) & OECD countries & $1971-2004$ & Tax $\leftarrow$ Growth \\
\hline Zhixin and Ya (2011) & China & 1999-2008 & Tax $\rightarrow$ Growth \\
\hline $\begin{array}{l}\text { Ojede and Yamarik } \\
(2012)\end{array}$ & United States & $1967-2008$ & Tax $\rightarrow$ Growth \\
\hline $\begin{array}{l}\text { Abdullah and Morley } \\
\text { (2014) }\end{array}$ & EU and OECD countries & $1995-2006$ & Tax $\leftarrow$ Growth \\
\hline $\begin{array}{l}\text { Fricke and Süssmuth } \\
(2014)\end{array}$ & Latin America & $1990-2009$ & Tax $\leftarrow$ Growth \\
\hline $\begin{array}{l}\text { Adkisson and } \\
\text { Mohammed (2014) }\end{array}$ & United States & 2004-2010 & Tax $\rightarrow$ Growth \\
\hline Kate and Milionis (2019) & OECD countries & $1965-2014$ & Tax $\rightarrow$ Growth \\
\hline \multicolumn{4}{|l|}{ Taxation and trade } \\
\hline Tosun (2005) & MENA countries & 1980-1997 & Tax $\leftarrow$ Trade \\
\hline Agbeyegbe et al. (2006) & Sub-Saharan countries & 1980-1996 & Tax $\leftarrow$ Trade \\
\hline Mahdavi (2008) & $\begin{array}{l}\text { American, Central } \\
\text { American, East Asian, } \\
\text { South Asian, Sub- } \\
\text { Saharan African, North } \\
\text { African, Middle Eastern } \\
\text { and Mediterranean } \\
\text { countries }\end{array}$ & $1973-2002$ & Tax $\leftarrow$ Trade \\
\hline $\begin{array}{l}\text { Baunsgaard and Keen } \\
(2010)\end{array}$ & $\begin{array}{l}\text { Africa, Asia Pacific, } \\
\text { Middle East, North } \\
\text { Africa and Western } \\
\text { Hemisphere countries }\end{array}$ & $1975-2006$ & Tax $\leftarrow$ Trade \\
\hline Hisali (2012) & Uganda & $1994-2010$ & Tax $\leftarrow$ Trade \\
\hline Epaphra (2014) & Tanzania & $1979-2010$ & Tax $\leftarrow$ Trade \\
\hline Gaalya (2015) & Uganda & 1994-2012 & Tax $\leftarrow$ Trade \\
\hline Nwosa et al. (2012) & Nigeria & $1970-2009$ & Tax $\leftarrow$ Trade \\
\hline
\end{tabular}




\begin{tabular}{llcc}
\hline \multicolumn{1}{c}{ Author(s) } & \multicolumn{1}{c}{ Countries } & Estimation period & $\begin{array}{c}\text { Direction of } \\
\text { causalities }\end{array}$ \\
\hline $\begin{array}{l}\text { Taxation and finance } \\
\text { Albertazzi and } \\
\text { Gambacorta (2010) }\end{array}$ & $\begin{array}{l}\text { European countries, } \\
\text { United States and } \\
\text { United Kingdom }\end{array}$ & $1981-2003$ & Tax $\rightarrow$ Finance \\
Tagkalakis (2011) & $\begin{array}{l}\text { OECD countries } \\
\text { Germany, United } \\
\text { (2013) }\end{array}$ & $1970-2005$ & Tax $\leftarrow$ Finance \\
& $\begin{array}{l}\text { Kingdom and United } \\
\text { States }\end{array}$ & $1991-2010$ & Tax $\rightarrow$ Finance \\
$\begin{array}{l}\text { Dornean and Oanea } \\
\text { (2015) }\end{array}$ & Romania & $199-2013$ & Tax $\rightarrow$ Finance \\
\hline \hline
\end{tabular}

Source: Author's compilation

Some empirical studies also focused on the discussion of the fiscal policy impact on the growth of financial activities. As the relationship between financial markets, fiscal policy and the economy have revived the attention of the researchers; our understanding of the nexus is far from complete. This is due to the voluminous number of determinants, which can influence the nature of the relationship. The earlier wave of studies suggests the significant impact of fiscal policy on stock market returns (Brocato 1994). Next, the fiscal policy reformation may distort or promote the financial market development. Looking at different aspects of the fiscal policy impact of fiscal policy changes on financial stability, Tagkalakis (2013) further argues that weak fiscal policies resulted in a negative impact on market confidence later could cause a risk to the economy, and hence caused financial instability. The reliance of financial market movement on the stability of the economy caught Bierbrauer's (2014) attention with a confirmation of the role of tax in contributing to the financial distress. We found, Tagkalakis (2013) and Bierbrauer (2014) views are contradicting with earlier discussion by Afonso and Sousa (2011), where fiscal shock only plays a minor role in the market transaction.

Tagkalakis (2011) also investigated the impact of financial market movements on fiscal policy outcomes and proved the positive impact of an increase in asset prices on government revenue. Recent study by Allen et al. (2018) emphasized on the role of financial market in promoting trade activities thus shifting the way trade liberation and tax reform were executed. In general, it is concluded that financial system does matter to tax reformation. Erosa and Gonzalez (2019) investigated how different form of taxing capital income affect firm's investment and finance over their life cycle which have direct effects on corporate income tax collection of the nation. Another cohort of studies done by Honohan and Klingebiel (2003), and Dornean and Oanea (2015) analyzed the impact of past financial and banking crises on taxation. Notably, accommodating policies to protect the financial stability in the event of economic crises tend to increase the fiscal cost. Despite the status of the country, rich and poor alike, fiscal policy stance needs to adjust according to economic stage: expansion or recession. According to Gilbert and Ilievski (2016), an improved financial system makes banking more attractive to the investors, thus increases banking activities as well as increased tax revenue.

Most of the previous studies have shown that further investigations are required mainly in reference to financial and trade issues in taxation for emerging economies. Therefore, the empirical results of the present study will offer a comprehensive insight for researchers in the field. The rest of this 
article is structured as follows. The next section will define the data and model specification settings. Section 3 will present and discuss the empirical results, and the final section will conclude.

\section{METHODOLOGY}

This study uses annual time series data covering the period from 1970 to 2017 for the emerging economy of Malaysia. We obtained the data from World Development Indicators from the World Bank (2018) based on the availability of the series of data and all series are valued in US dollar. As mentioned in the literature, many studies have used trade openness, financial development and growth as a major contributor for taxation. In line with prior studies, we followed those ideas and we created our own financial development index comprising major financial indicators to identify the determinants of taxation in Malaysia. Thus, the following taxation-trade-financial-growth functional relationship in the present study is as follows:

$\operatorname{Tax}_{t}=f\left(\operatorname{Trade}_{t}^{\beta_{1}}, F D_{t}^{\beta_{2}}, G D P C_{t}^{\beta_{3}}, G D P C_{t}^{2^{\beta_{4}}}\right)$

where, Tax is the total tax revenue as percentage of GDP, Trade is the volume of trade, $F D$ is the financial development, $G D P C$ and $G D P^{2}$ represents the per capita gross domestic product and the squared value, respectively; and $\mu$ is the error term. In order to determine the effects of growthled-tax revenue, we employ the GDPC and the GDPC squared series to mainly capture the U-shape effect between both tax revenue and economic sustainability. On the other hand, Trade and FD series are meant to capture the economic openness and financial quality on the taxation performance of Malaysia. Therefore, the proposed logarithm formation of linear equation of this study can be illustrated as follows:

$\operatorname{lnTax}_{t}=\beta_{0}+\beta_{1} \operatorname{lnTrade}_{t}+\beta_{2} \operatorname{lnFD} D_{t}+\beta_{3} \operatorname{lnGDPC} C_{t}+\beta_{4} \operatorname{lnGDPC} C_{t}^{2}+\mu_{t}$

All variables are measured in US dollar and are expressed in natural logarithm to capture the elasticity coefficient effects in the long run. To construct the financial instability series, we emphasized the Principle Component Analysis (PCA) and this application will overcome the multicollinearity problem, since most of the financial variables are highly correlated among themselves (Samargandi et al., 2015). Rather than using single financial proxy series, the financial development index will be a suitable indicator to capture the overall financial condition. We follow Samargandi et al. (2015) and Uddin et al. (2013) among others, who combined the liquid liabilities (M2) as the ratio of money (M1), domestic credit provided by the banking sector as a percentage of GDP; and domestic credit provided for private sectors as a percentage of GDP. As the first step, in the present study we are testing for the unit roots of each variable used in study. We use the traditional augmented Dickey and Fuller (1981) and the recent Perron (1997) unit root tests. These tests are employed to capture the potential unknown single break for the series.

Once all series passed the unit root test, then we extend our empirical analysis by performing cointegration analysis. First, we applied the most recent Maki (2012) cointegration test. Compared to regular cointegration tests, this test can determine the long-run relationship within the variables with more than one structural break effects. The Maki (2012) cointegration approach involves 4 different models as shown below: 
Level shift

$y_{t}=\mu+\sum_{i=i}^{k} \mu_{i} K_{i}+\beta x_{t}+\varepsilon_{t}$

Level shift with trend

$y_{t}=\mu+\sum_{i=i}^{k} \mu_{i} K_{i, t}+\beta x_{t}+\sum_{i 10}^{k} \beta_{i} x_{i} K_{i, t}+\varepsilon_{t}$

Regime shift

$y_{t}=\mu+\sum_{i=1}^{k} \mu_{i} K_{i, t}+\delta_{x}+\beta x_{i}+\sum_{i=1}^{k} \beta_{i} x_{i} K_{i, t}+\varepsilon_{t}$

Trend and regime shift

$y_{t}=\mu+\sum_{i=1}^{k} \mu_{i} K_{i, t}+\delta t+\sum_{i=1}^{k} \delta_{i} t K_{i, t}+\beta x_{t}+\sum_{i=1}^{k} \beta_{i} x_{i} K_{i, t}+\varepsilon_{t}$

where, $y_{t}$ and $x_{t}$ represent the estimated variables and $K_{i}$ series represent a dummy series in all four regression models to test for the cointegration condition with numbers of structural breaks. While, the dummy variable for Maki's cointegration estimation can be defined as follows:

$K_{i}=\left\{\begin{array}{l}1 \\ 0\end{array}\right.$, when $t>T_{B}$ and otherwise

where, $T_{B}$ represents the break point for the regressions and to determine the cointegration condition with structural breaks, and we will identify the long run cointegration based on the critical values (see Table 1) proposed by Maki (2012). Next, to investigate the short and long run cointegration among the variables, we used the bounds test within the Autoregressive Distributed Lag (ARDL) application developed by Pesaran et al. (2001). The dependent variable may not immediately adjust from short-run unstable condition to long-run equilibrium level. Therefore, we employ the error correction term through the ARDL model which is reflected as ARDL-ECM model as shown in Eq. (8). This ARDL-ECM is suitable to be used for purely $I(0), I(1)$ or mixture of $I(0)$ and $I(1)$ regressors. 


$$
\begin{aligned}
\Delta \operatorname{Tax}_{t}= & \beta_{0}+\sum_{i=1}^{p} \alpha_{1} \Delta \operatorname{Tax}_{t-i}+\sum_{i=0}^{p} \alpha_{2} \Delta \operatorname{Trade}_{t-i}+\sum_{i=0}^{p} \alpha_{3} \Delta F D_{t-i}+\sum_{i=0}^{p} \alpha_{4} \Delta G D P C_{t-i}+ \\
& \sum_{i=0}^{p} \alpha_{5} \Delta G D P C_{t-i}^{2}+\pi_{1} \operatorname{Tax}_{t-1}+\pi_{2} \text { Trade }_{t-1}+\pi_{3} F D_{t-1}+\pi_{4} G D P C_{t-1}+\pi_{5} G D P C_{t-1}^{2} \\
& +\gamma \text { ect }_{t-1}+\varepsilon_{i}
\end{aligned}
$$

In Eq. (8), $\Delta$ represents the difference operator for each variable involved in this study. While, $\varepsilon_{t}$ is the serially independent random error with zero mean and finite covariance matrix. The error correction term is represented by $\gamma$ and the coefficient condition must be statistically significant, and negative, which implies that the dependent variable convergence to the long-run equilibrium level of the independent variables unstable condition in the short-term period. In the present study, to capture the long-run relationship, we used the $F$-test with the null hypothesis as Ho: $\pi_{1}=\pi_{2}=\pi_{3}=\pi_{4}=\pi_{5}=0$ and the alternative hypothesis as Ho: $\pi_{1} \neq \pi_{2} \neq \pi_{3} \neq \pi_{4} \neq \pi_{5} \neq 0$. In the final step, the ARDL-ECM which involves the short and long-run relationship for the regressors are estimated, along with the diagnostic tests.

Finally, we employ the residual based bootstrap method to capture the bidirectional causal effect. To demonstrate this application, we followed Balcilar et al. (2010), and Li et al. (2016) the modified- $L R$ causality test based on the bootstrap critical values. In addition, Shukur and Mantalos (2000) proved that relatively small samples will more smoothly correct with the LR test and we therefore considered this approach in our study. In general, the full-sample causality estimation based on the vector autoregressive (VAR) model faced constant condition over the estimation period and when there are structural changes that appear, the estimated causal relationship will not be accurate and violated. This will lead to several issues on the stability of the estimated VAR model and the long-run causal relationship of the full-sample will be invalid. The following Eq. (9) express the rolling window causality test based on a modified- $L R$ statistics.

$\left(\begin{array}{l}y_{1 t} \\ y_{2 t}\end{array}\right)=\left(\begin{array}{l}\alpha_{1} \\ \alpha_{2}\end{array}\right)+\left(\begin{array}{ll}\alpha_{11}(L) & \alpha_{12}(L) \\ \alpha_{21}(L) & \alpha_{22}(L)\end{array}\right)\left(\begin{array}{l}y_{1 t} \\ y_{2 t}\end{array}\right)+\left(\begin{array}{l}\varepsilon_{1 t} \\ \varepsilon_{2 t}\end{array}\right)$

where, $y_{1 t}$ and $y_{2 t}$ represent the Tax and GDPC, respectively. While, $L$ is the lag operator define as $L^{k} x_{t}=x_{t-k}$, and;

$\alpha_{i j}(L)=\sum_{k=1}^{p+1} \alpha_{i j, k} L^{k}, i, j=1,2, \ldots . n$

\section{EMPIRICAL RESULTS}

We begin our analysis with descriptive statistics and correlation matrix for all series involved in this study. Table 3 shows the results of both descriptive and correlation matrix and we found that all series are in a stable mode. For example, in terms of normality condition, we found that all series are normality distributed, except for the financial development series. This is not such an issue. As mentioned earlier, the financial development series is created using the PCA and this compressed three financial series which always fluctuate over time. The first component of the PCA, explain the highest frequency compared to component 2 and 3 in this study. Therefore, we 
can conclude that, the estimated first component of the PCA has the maximum explanatory power and we used this series as our financial development fundamental indicator, namely FD.

Table 3: Descriptive Statistics and Correlation Matrix

\begin{tabular}{lccccc}
\hline \hline & $\boldsymbol{T a x}$ & Trade & $\boldsymbol{F D}$ & $\boldsymbol{G D P C}$ & $\boldsymbol{G D P C}^{\mathbf{2}}$ \\
\hline Median & 10.318 & 12.316 & -0.003 & 8.211 & 67.435 \\
Maximum & 12.053 & 14.187 & 0.341 & 8.896 & 79.142 \\
Minimum & 7.5585 & 9.048 & -0.346 & 7.263 & 52.757 \\
Std. Dev. & 1.2245 & 1.618 & 0.101 & 0.476 & 7.736 \\
Skewness & -0.377 & -0.325 & 0.050 & -0.198 & -0.133 \\
Jarque-Bera & 12.116 & 13.555 & $25.530^{* * *}$ & 2.960 & 2.971 \\
(p-value) & $(0.347)$ & $(0.168)$ & $(0.000)$ & $(0.227)$ & $(0.226)$ \\
\hline \multicolumn{7}{c}{ Correlation matrix } \\
Tax & $\mathbf{1}$ & & & \\
Trade & $0.987 * * *$ & $\mathbf{1}$ & & \\
FD & $(0.000)$ & 0.005 & $\mathbf{1}$ & \\
GDPC & 0.065 & $(0.970)$ & & & \\
& $(0.671)$ & $0.995 * * *$ & 0.034 & $\mathbf{1}$ & \\
GDPC & $0.992^{* * *}$ & $(0.000)$ & $(0.824)$ & & \\
& $(0.000)$ & $0.993 * * *$ & 0.031 & $0.999 * * *$ & $(0.000)$ \\
\hline \hline
\end{tabular}

Note: Statistically significant at $1 \%(* * *), 5 \%(* *)$ and $10 \%(*)$ level.

Next, we proceeded with the traditional ADF unit root test. We found that, all series are integrated at first difference or $I(1)$. Concurrently, we also conducted the Perron (1997) unit root test, which can capture single unknown annual break date. The results displayed slight contradiction with ADF test result, where the financial development series are integrated at $I(0)$ level. Again, this is in line with the normality problem appeared in the earlier stage and this mixed condition of $I(0)$ and $I(1)$ unit root tests results will not limit our estimation direction because we assumed all series are integrated at $I(1)$ based on the ADF test results (see Table 4). Once all series are found to be integrated at $I(1)$ throughout this study, we extended the analysis with Maki (2012) and Pesaran et al. (2001) bounds long-run cointegration effects.

Table 4: Unit Root Test Results

\begin{tabular}{lcccc}
\hline \hline \multirow{2}{*}{ Variables } & \multicolumn{2}{c}{ At level } & \multicolumn{2}{c}{ At first difference } \\
\cline { 2 - 5 } Tax & ADF & Perron & ADF & Perron \\
& -2.025 & -2.883 & $-4.506^{* * *}$ & $-6.075^{* * *}$ \\
Trade & & $(1997)$ & & $(1987)$ \\
& -1.860 & -2.329 & $-5.744^{* * *}$ & $-7.499^{* * *}$ \\
FD & & $(2007)$ & & $(1986)$ \\
& -2.032 & $-7.086^{* * *}$ & $-10.429 * * *$ & $-12.658^{* * *}$ \\
GDPC & & $(1992)$ & & $(1992)$ \\
& -1.458 & -2.895 & $-5.690^{* * *}$ & $-7.008^{* * *}$
\end{tabular}




\begin{tabular}{lcccc}
\hline \multirow{2}{*}{ Variables } & \multicolumn{2}{c}{ At level } & \multicolumn{2}{c}{ At first difference } \\
\cline { 2 - 5 } & ADF & Perron & ADF & Perron \\
\hline \multirow{2}{*}{ GDPC $^{2}$} & \multirow{2}{*}{-1.011} & $(1997)$ & & $(1998)$ \\
& & -3.102 & $-5.842^{* * *}$ & $-5.580^{* *}$ \\
& & $(1990)$ & & $(1992)$ \\
\hline \hline
\end{tabular}

Note: Statistically significant at $1 \%(* * *), 5 \%(* *)$ and $10 \%(*)$ level. Values in ( ) indicate the break date based on Perron (1997) unit root test.

Table 5 reports the Maki (2012) cointegration test results with several unknown breaks. Based on the estimated results, we accept the cointegration between the fundamental function of this study, where model 1 and 3 have rejected the null hypothesis of no long run cointegration at $10 \%$ significance level, respectively. In addition, the break data seems to have almost similar subperiods for model 2 and 3, which is at 1985 and 1997. Eventually, these entire break dates are significant with global oil price crises in the 1985; and Asian financial crises in late 1990's.

Table 5: Maki Cointegration Test Results

\begin{tabular}{cccc}
\hline \hline Estimation models & Statistic value & Critical value (10\%) & Break data \\
\hline Model 1 & -5.535 & -5.714 & $1977 ; 1989 ; 2003$ \\
Model 2 & -5.717 & -5.974 & $1978 ; 1992 ; 1997$ \\
Model 3 & $-7.874 * * *$ & -7.481 & $1984 ; 1989 ; 2002$ \\
Model 4 & $-8.393 * * *$ & -7.977 & $1978 ; 1985 ; 1997$ \\
\hline \hline
\end{tabular}

Note: Statistically significant at $1 \%(* * *), 5 \%(* *)$ and $10 \%\left({ }^{*}\right)$ level. The critical value is gathered from Table 1 Maki (2012)

We also performed the ARDL bounds test estimation. This test is well known for series with mixed unit root conditions. The main reason for using this test is to strengthen our long run cointegration effects, since we obtained mixed results in the order of integration when dealing with the Perron (1997) unit root test. The use of bounds tests through the ARDL modeling suggested by Pesaran et al. (2001) with critical values for $F$-statistics (as in Table 6) clearly shows that, both ARDL bounds estimates without and with break date $\left(T_{B}=1997\right)$ rejected the null hypothesis of no cointegration at $1 \%$ and $10 \%$ significance level, respectively. Consequently, we found that both Maki cointegration and ARDL bounds test indicated the same long run cointegration condition.

With consistent results from Maki (2012) and the bounds test, next we continued with ARDLECM estimates (see Table 7). We found that the financial development variable has impacted the pattern of tax revenue collected positively in both short and long-term periods. This result was consistent with the cyclical movement of this variable, which is consistent with previous findings by Honohan and Klingebiel (2003), and Dornean and Oanea (2015). Even though our findings are contradictory to Barro (1990) and Adkisson and Mohammed (2014), our finding suggests that a higher revenue collection does not have a significant impact in fostering the growth, which also does not support the supply-side hypothesis. In the case of the link between trade openness and taxation, the study discovered that trade openness is positively linked to taxation and it's statistically significant at the 5\% level at both short and long run. We found that an increase in trade openness has led a high volume of increases in tax revenues, which mainly comes from tariffs. The relationship between economic growth and taxation on the other hand, is found to be highly 
positive and statistically significant at the $1 \%$ level for both short and long run. In addition to this, we also discovered that the squared economic series is negatively significant with taxation and confirms the diminishing return condition in this study with the growth-led-taxation effects for Malaysia.

Table 6: ARDL $F$-Bounds Test

\begin{tabular}{lccccc}
\hline $\begin{array}{l}\text { Dependent variable: } \\
\boldsymbol{T a x}\end{array}$ & $\boldsymbol{k}$ & $\boldsymbol{F}$-statistic & $\begin{array}{c}\boldsymbol{F} \text {-statistic } \\
\left(\boldsymbol{T B}_{\mathbf{1 9 9 7})}\right.\end{array}$ & $\begin{array}{c}\text { Null } \\
\text { hypothesis }\end{array}$ & $\begin{array}{c}\text { Long-run } \\
\text { cointegration }\end{array}$ \\
\hline ARDL $(1,2,2,0,0)$ & 4 & $2.833^{*}$ & & $H_{o}$ rejected & $\checkmark$ \\
ARDL(1,2,2,0,0,0) & 5 & & $3.490^{* * *}$ & $H_{o}$ rejected & $\checkmark$ \\
\hline Significance levels & & Lower & Upper & & \\
& bound & bound & \\
\hline $10 \%$ & 2.45 & 2.26 & \\
$5 \%$ & 2.86 & 2.62 & \\
$1 \%$ & & 3.74 & & \\
\hline \hline
\end{tabular}

Note: Statistically significant at $1 \%(* * *), 5 \%(* *)$ and $10 \%\left({ }^{*}\right)$ level. The break date is 1997 based on the Perron (1997) unit root test null hypothesis rejection of no cointegration with structural break. The critical values are based on Pesaran et al. (2001). The optimal lag selection is based on the Akaike Information Criterion (AIC) with the VAR estimation ( $k=3$ )

To validate the continuum of the overall findings obtained, this study also discovers the time break effect and found that, the break condition has a positive effect on tax revenue in Malaysia. The estimate of the lagged error correction term has a negative sign and statistically significant at $5 \%$ and $10 \%$ levels, respectively at both conditions namely with and without break. The lagged error correction term is equivalent to -0.110 (without break) and -0.087 (with break) respectively and theoretically with the right negative sign suggesting a convergence from short-run to long-run equilibrium condition. This simply means that, the short-run variations are corrected as speedy as $10 \%$ and $8 \%$ for tax revenues long-run condition with the fundamental function in this study. When discussing about the diagnostic tests results of this study, we found all diagnostic tests are in the stable mode without any problem (see Table 7). This study also found a positive coefficient of GDPC and negative coefficient of GDPC squares. This result supports the existence of the inverse U-shape relationship between taxation reform and GDPC in Malaysia. This suggests that, as the countries' economy is progressing well (from low to higher level), the tax revenue at first will increase and eventually after a certain level of optimum point, the tax revenue will tend to decrease. According Aghion et al. (2016), the inverted U-shape relationship between taxation and growth will tend to improve the provision of public goods which makes small and large firms more productive and create disincentives to investment.

Table 7: Long and Short-Run Estimation Results

\begin{tabular}{|c|c|c|c|c|}
\hline \multirow{3}{*}{ Variables } & \multicolumn{4}{|c|}{ Dependent variable: $\operatorname{Tax}$} \\
\hline & \multicolumn{2}{|c|}{ Without break } & \multicolumn{2}{|c|}{ With break } \\
\hline & Coefficient & $t$-stats & Coefficient & $t$-stats \\
\hline \multicolumn{5}{|c|}{ Long-run estimates } \\
\hline Trade & $\begin{array}{c}1.187 * * \\
(0.456)\end{array}$ & 2.600 & $\begin{array}{l}1.216^{* *} \\
{[0.546]}\end{array}$ & 2.223 \\
\hline
\end{tabular}




\begin{tabular}{|c|c|c|c|c|}
\hline \multirow{3}{*}{ Variables } & \multicolumn{4}{|c|}{ Dependent variable: $\operatorname{Tax}$} \\
\hline & \multicolumn{2}{|c|}{ Without break } & \multicolumn{2}{|c|}{ With break } \\
\hline & Coefficient & $t$-stats & Coefficient & $t$-stats \\
\hline \multicolumn{5}{|c|}{ Long-run estimates } \\
\hline$F D$ & $\begin{array}{c}0.757 * * \\
(0.344)\end{array}$ & 2.201 & $\begin{array}{c}-0.973 * * \\
{[0.453]}\end{array}$ & -2.149 \\
\hline$G D P C$ & $\begin{array}{c}1.492 * * * \\
(0.532)\end{array}$ & 2.807 & $\begin{array}{l}1.025 * * \\
{[0.470]}\end{array}$ & 2.176 \\
\hline$G D P C^{2}$ & $\begin{array}{c}-0.676^{* *} \\
(0.307)\end{array}$ & -2.202 & $\begin{array}{c}-0.704 \\
{[0.416]}\end{array}$ & -1.689 \\
\hline$T B_{1997}$ & & & $\begin{array}{c}0.017 * * * \\
{[0.010]}\end{array}$ & 2.101 \\
\hline \multicolumn{5}{|c|}{ Short-run estimates } \\
\hline Trade & $\begin{array}{c}0.357 * * \\
(0.173)\end{array}$ & 2.088 & $\begin{array}{l}0.362^{*} \\
(0.181)\end{array}$ & -1.994 \\
\hline$F D$ & $\begin{array}{c}0.314 * * \\
(0.146)\end{array}$ & 2.143 & $\begin{array}{l}0.2087 \\
(0.126)\end{array}$ & 1.648 \\
\hline$G D P C$ & $\begin{array}{c}1.475 * * * \\
(0.526)\end{array}$ & 2.807 & $\begin{array}{l}1.660 * * \\
(0.740)\end{array}$ & 2.245 \\
\hline$G D P C^{2}$ & $\begin{array}{c}-0.250 * * \\
(0.115)\end{array}$ & -2.164 & $\begin{array}{c}-0.2601 * \\
(0.151)\end{array}$ & -1.713 \\
\hline$T B_{1997}$ & & & $\begin{array}{c}0.006 \\
(0.064) \\
\end{array}$ & 0.101 \\
\hline Diagnostic tests & $F$-stats & $p$-value & $F$-stats & $p$-value \\
\hline$\chi_{A R C H}^{2}$ & 0.444 & 0.509 & 0.461 & 0.500 \\
\hline$\chi_{\text {Nornality }}^{2}$ & 1.838 & 0.398 & 1.774 & 0.411 \\
\hline$\chi_{\text {Serial }}^{2}$ & 0.357 & 0.702 & 0.365 & 0.696 \\
\hline$\chi_{\text {Hetero }}^{2}$ & 0.343 & 0.953 & 0.682 & 0.732 \\
\hline
\end{tabular}

Note: Statistically significant at $1 \%(* * *), 5 \%(* *)$ and $10 \%(*)$ level. Values in [ ] and ( ) represent standard errors and $p$ - values, respectively.

The estimated graphs of the cumulative sum (CUSUM) and the cumulative sum of the squares (CUSUMQ) are presented in Fig. 1 for both models. Only the CUSUM graph of the model with structural break period function shows instability as it exceeds the critical bounds at the $5 \%$ level. To overcome this issue, we employ the Chow breakpoint test and confirm that there is no break point condition for the two unstable sub-periods which exceed the bounds. Therefore, we confirm that our estimated model is fit and acceptable. Due to the problem shown in Fig. 1, we found that the CUSUM value has progressively departed from that of the benchmark in the year 2002 showing the potential to break. This out of control situation resulted from the high saving rate and abundant liquidity in the domestic financial system (Bank Negara Malaysia, 2012). The Malaysian government shows strong commitment to restore the success of the Malaysian bond market by reopening Malaysia's Global US Dollar Bond and issued the first Global Islamic Trust Certificates to offer an incentive for the development of the international Islamic financial market in year 2012. This effort has assisted the sustainability of financial position in Malaysia and further gained the investors' confidence level. This proactive measure by the government has contributed to the expansion of GDP to $4.2 \%$ as compared to $0.4 \%$ in 2001 . 
Figure 1: CUSUM and CUSUMQ at 5\% significance level with and without break
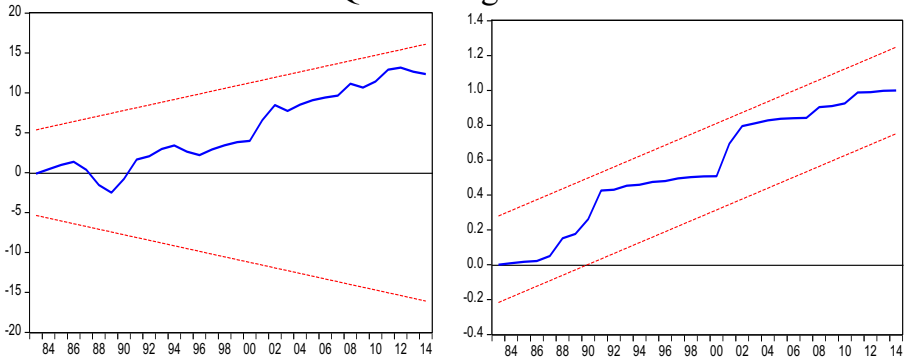

(i) Without break
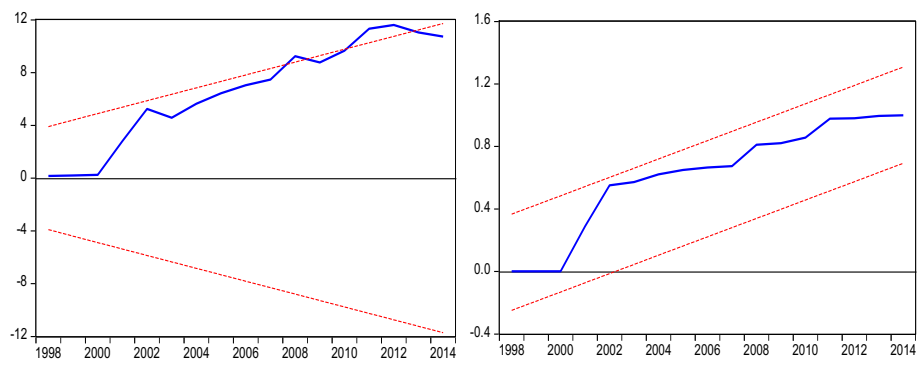

(ii) With break $\left(T B_{1997)}\right.$

The positive environment in financial market activity and the growth performance facilitated high tax revenue collection in Malaysia to RM44,324 million as compared to RM41,794 million showing an increase of $6.05 \%$. On top of the positive contribution from the financial market related activity and GDP, this commendable increase was achieved through the relaxation of tax regulation and the implementation of the Self-Assessment System (SAS) which encouraged high compliance by the organization (Bank Negara Malaysia, 2002), and the right mix of policy implemented by the Malaysian government to facilitate its recovery from the Asian financial crises. Moreover, we used rolling windows full sample causality test and found that there is only unidirectional causality running from financial instability to taxation; and causality running between economic growth and taxation (see Table 8).

Table 8: Full sample Granger causality test results

\begin{tabular}{lcc}
\hline \hline \multicolumn{1}{c}{ Causality Directions } & LR -statistics & Bootstrap $\boldsymbol{p}$-value \\
\hline Tax $-/ \rightarrow$ Trade & 2.874 & 0.285 \\
Tax $\leftarrow /-$ Trade & 9.809 & 0.108 \\
Tax $-/ \rightarrow F D$ & 3.644 & 0.297 \\
Tax $\leftarrow /-F D$ & $8.489^{* *}$ & 0.020 \\
Tax $-/ \rightarrow G D P C$ & 1.805 & 0.483 \\
Tax $\leftarrow /-G D P C$ & $22.230^{* * *}$ & 0.007 \\
Tax $-/ \rightarrow G D P C^{2}$ & 1.552 & 0.560 \\
Tax $\leftarrow /-G D P C^{2}$ & $21.45^{* * *}$ & 0.005 \\
\hline \hline
\end{tabular}

Note: $* * *$, and $* * *$ denote significance at $10 \%, 5 \%$, and $1 \%$, respectively. The p-values are obtained through 2000 Monte Carlo simulations 
Although, we are able to determine the causalities but, in some cases, this results are not really acceptable because in some circumstances, there will be partial causalities in a certain sub-period of the study, which has been explored by Li et al. (2016), and Balcilar et al. (2010). The bootstrap p-values of the rolling-window test statistics causal relation from TR to CPI are shown in Figure 2, 3 and 4. Through Figure 2 (a), we found a long range of a single period of predictive power of causality running between Tax on Trade. While, for Figure 2 (b), there is only short range of single predictive power of Trade caused Tax, which is in 1993-1995. The predictive power of causality was reported in 1990 which is due to the abolition of dual listing of Malaysian companies in the Stock Exchange of Singapore (SES) and Kuala Lumpur Stock Exchange (KLSE) which contribute to temporary crash in January 1990. The later years show the recovery of financial market before the period of the Asian financial crisis in 1997. During the period after 1997 Asian financial crises there is a series of crises namely Dot-com bubble 2000, Severe Acute Respiratory Syndrome (SARS) in 2003, and Global Financial Crises in 2008 which have affected the Malaysian economy.

Figure 3 (a) show the effects of Tax on FD and we found that there is a very short effect of predictive power arise in 2004. Furthermore, there is no predictive power that emerged on the Tax caused FD as shown in Figure 3 (b). The downward trend in the financial market in 2008 resulted in the decline of performance in revenue collection. Despite of these crises, the Malaysian government efficiency in shaping policy has assisted in the recovery process in 2010 and in 2012 to recover from the unstable economic condition caused by oil price fluctuations. Figure 4 indicates that Tax have three predictive power caused on GDPC. Given this result, we realize that there is a strong taxation-led-growth, and there are no predictive power of causality running between GDPC on Tax. We also realize that, most of the sums of the coefficients that Tax affects GDPC are on the positive side.

In Table 9, we found that the Sup-LR, Exp-LR and Mean which indicating the short-run parameters' stabilities. In this study, we used fractional samples in 15\% trimming on both ends of the estimated period $(0.15,0.85)$ Monte Carlo bootstrap simulations. The estimated short-run parameter stability indicates that, Tax causes FD has the full short-run stability condition, and Tax caused Trade has only Sup-LR effects. Surprisingly, Tax causes GDPC does not show any shortrun stability. On the other hand, we found that none of the estimation causality parameter facing the short run-stability. Furthermore, we followed Nyblom (1989) approach to determine the Hansen stability test based on the Fully-Modified OLS (FMOLS) estimates, and the results are stated as $L_{c}$ (see Table 9). This estimated value is important to capture the long-run parameter stability of each of the causal relationship under the rolling window estimation and we conclude that all of the estimated causal parameters' have long-run parameter stability as the null hypothesis of Hansen stability estimation is rejected.

Table 9: Parameter Stability Test Results

\begin{tabular}{lcccc}
\hline \hline & \multicolumn{2}{c}{ Equation for series: $\boldsymbol{T a x}$} & \multicolumn{2}{c}{ Equation for series: $($ Trade/FD/GDP) } \\
\cline { 2 - 5 } & Statistics & Bootstrap $\boldsymbol{p}$-values & Statistics & Bootstrap $\boldsymbol{p}$-values \\
\hline Tax and Trade & & & & \\
Sup-LR & $4.619^{*}$ & 0.064 & 2.580 & 0.390 \\
Exp-LR & 0.895 & 0.140 & 0.788 & 0.212 \\
Mean-LR & 1.133 & 0.337 & 1.489 & 0.182 \\
$L_{c}$ & $0.296^{*}$ & 0.053 & $0.269^{*}$ & 0.081
\end{tabular}




\begin{tabular}{lcccc}
\hline \hline & \multicolumn{2}{c}{ Equation for series: Tax } & \multicolumn{2}{c}{ Equation for series: $($ Trade/FD/GDP) } \\
\cline { 2 - 5 } & Statistics & Bootstrap $\boldsymbol{p}$-values & Statistics & Bootstrap $\boldsymbol{p}$-values \\
\hline Tax-FD & & & & \\
Sup-LR & $4.331^{*}$ & 0.081 & 0.971 & 0.899 \\
Exp-LR & $1.042^{*}$ & 0.091 & 0.186 & 0.907 \\
Mean-LR & $1.817^{*}$ & 0.092 & 0.355 & 0.901 \\
$L_{c}$ & $0.958^{* * *}$ & 0.000 & $0.766^{* * *}$ & 0.000 \\
& & & & \\
Tax-GDPC & & & \\
Sup-LR & 3.696 & 0.125 & 2.838 & 0.279 \\
Exp-LR & 0.899 & 0.125 & 0.595 & 0.3085 \\
Mean-LR & 1.549 & 0.127 & 1.022 & 0.322 \\
$L_{c}$ & $0.438^{*}$ & 0.059 & $0.523^{* *}$ & 0.035 \\
\hline \hline
\end{tabular}

Note: $* * *$, and $* * *$ denote significance at $10 \%, 5 \%$, and $1 \%$, respectively. The $p$-value is calculated using 1000

Monte Carlo bootstrap simulations. The lag length operator for rolling window estimation is based on AIC from the VAR estimates $(k=3)$

\section{CONCLUSION}

Despite this turmoil, the Malaysian government has played an active role in development planning to secure balanced economic growth and combat future recession. The most recent policy on indirect taxes implemented by introducing Goods and Services Tax (GST) in 2015 meant to avoid the dependency on direct taxes, which will be stagnant as the main contribution to direct tax comes from petroleum tax which will be depleted in the future years. To date, research scholars divert their focus in examining the nexus between these macroeconomic indicators to capture how these factors contribute to the growth of an economy. Bearing this in mind our study aims to analyze the dynamic relationship between trade openness, per capita GDP, and financial instability on taxation. The results of this study found that economic growth positively affects both short-run and longrun tax revenue and financial instability (Abdullah and Morley, 2014; Fricke and Süssmuth, 2014). One direct explanation is that the progressive effort taken by Malaysian government to protect financial market conditions have facilitated economic growth hence resulted in an increase in revenue collection. In the event of financial market turmoil, government needs to step in to rescue the economy, which in turn had direct and indirect fiscal costs. Direct fiscal cost involved permanent decrease in government's net worth due to financial system rescue packages and indirect fiscal cost involved the reduction in government revenue due to falling profits. Thus, the decision made by the government on the country's debt and revenue could also become a risk to financial market stability.

Series of recession experienced by Malaysia resulted in the implementation of fiscal cuts such a capital reduction by the government, which lowered GDP growth and reduces revenue collection. This fiscal cut however was meant to be a short-term measure to stabilize the economy. In the longterm, specifically during post-recession period, the government removed some of the fiscal policies to gain investors' confidence. For instance, from the period from 2001 to 2005 the government relaxed the capital control implementation to attract foreign investment, with the abolishment of exit levies, which stopped the outflow of revenue from Malaysia in 2001 (Lim and Goh, 2012). 
Also, Yong et al. (2019) found that GST imposition reduces the trading volume in the Bursa Malaysia. It is also worth noting that trade openness through tariff reduction had no short and long-run impact on tax revenue collection. This hints that there are chances for the government to be more liberal on trade without any concern on the inability of revenue generation. As economic growth contributes to steady tax revenue, failure to capitalize on the benefit of the growth will cause the nation to miss a chance to create long-term fiscal stability and opportunity to improve the quality of life for their citizens. Although trade and financial liberalization increase economic and financial activities, it could also reflect the declining trade tax collection and overall revenue if it is not compensated by other types of taxes, as the services and sales tax (SST) is reintroduced in 2018. Higher growth creates opportunities for tax evasion; thus, tax administrator should prioritize more aggressive measures by incorporating effective enforcement. The country needs more redistribution to be carried out through the dynamic fiscal policy system. However, progressive tax collection is more difficult to be implemented in Malaysia to raise sufficient amounts of tax revenue as a long-term strategized fiscal policy. Therefore, the government should pay more attention on the effectiveness of the future public expenditure program and create more alternative sources of tax revenues.

\section{ACKNOWLEDGEMENT}

This research is funded under the Universiti Teknologi Malaysia Flagship Grant (UTM Shine: PY/2017/02187). We would like to thank Professor Mehmet Balcilar from Eastern Mediterranean University, Turkey for his valuable guides and rolling-window codes to conduct the bootstrap rolling window causality test successfully.

\section{REFERENCES}

Abdullah, S., \& Morley, B. (2014). Environmental taxes and economic growth: Evidence from panel causality tests. Energy Economics, 42, 27-33.

Adkisson, R. V., \& Mohammed, M. (2014). Tax structure and state economic growth during the great recession. The Social Science Journal, 51(1), 79-89.

Afonso, A., \& Sousa, R. M. (2011). What are the effects of fiscal policy on asset markets? Economic Modelling, 28(4), 1871-1890.

Agbeyegbe, T. D., Stotsky J., \& Wolde Mariam, A. (2006). Trade liberalization, exchange rate changes and tax revenue in Sub-Saharan Africa. Journal of Asian Economics, 17(2), 261284.

Aghion, P., Akcigit, U., Cage, J., \& Kerr, W. R. (2016). Taxation, Corruption and Growth. Harvard Business School Working Paper No. 16-075.

Albertazzi, U., \& Gambocorta, L. (2010). Bank profitability and taxation. Journal of Banking and Finance, 4(11), 2801-2810.

Arnold, J. M., Brys, B., Heady, C., Johansson, A., Scwellnus, C., \& Vartia, L. (2011). Tax policy for economic recovery and growth. The Economic Journal, 121(550), 59-80. 
Atems, B. (2016). Another look at a tax policy and state economic growth: The long-run and shortrun of it. Economics Letters, 127, 64-67.

Balcilar, M., Ozdemir, Z. A., \& Arslanturk, Y. (2010). Economic growth and energy consumption causal nexus viewed through a bootstrap rolling window. Energy Economics, 32(6), 13981410.

Bank Negara Malaysia. (2012). Economic Developments in 2012: Bank Negara Malaysia Annual Report 2012. Kuala Lumpur: Bank Negara Malaysia.

Barro, R. J. (1990). Government spending in a simple model of endogenous growth. Journal of Political Economy, 98(5), 103-125.

Baunsgaard, T., \& Keen, M. (2010). Tax revenue and (or?) trade liberalization. Journal of Public Economics, 94(9-10), 563-577.

Bierbrauer, F. (2014). Tax incidence for fragile financial markets. Journal of Public Economics, $120,107-125$.

Chandran, V. G. R., \& Munusamy, A. (2009). Trade openness and manufacturing growth in Malaysia. Journal of Policy Modeling, 31(5), 637-647.

Chatziantoniou, I., Duffy, D., \& Filis, G. (2013). Stock market response to monetary and fiscal policy shocks: Multi-country evidence. Economic Modelling, 30, 754-769.

Chen, P., Chu, A. C., Chu, H., \& Lai, C. (2017). Short-run and long-run effects of capital taxation on innovation and economic growth. Journal of Macroeconomics, 53, 207-221.

Choi, Y., \& Kim, S. (2016). Dynamic scoring of tax reforms in a small open economy model. Economic Modelling, 58, 182-193.

Dickey, D., \& Fuller, W. (1981). Likelihood ratio statistics for autoregressive time series with a unit root. Econometrica, 49(4), 1057-1072.

Dornean, A., \& Oanea, D. C. (2015). Romanian fiscal policy sustainability during financial crisis: A cointegration approach. Procedia Economics and Finance, 20, 163-170.

Durusu-Ciftci, D., Gokmenoglu, K. K., \& Yetkiner, H. (2018). The heterogeneous impact of taxation on economic development: New insights from a panel cointegration approach. Economic Systems, 42(3), 503-513.

Erosa, A., \& Gonzalez, B. (2019). Taxation and the life cycle of firms. Journal of Monetary Economics, 105, 114-130.

Fricke, H., \& Süssmuth, B. (2014). Growth and volatility of tax revenues in Latin America. World Development, 5, 114-138.

Gaalya, M. S. (2015). Trade liberalization and tax revenue performance in Uganda. Modern Economy, 6(2), 228-244.

Gilbert, S., \& Ilievski, B. (2016). Banks, development and tax. The Quarterly Review of Economics and Finance, 61, 1-13.

Haque, M. E., \& Mukherjee, A. (2005). On the revenue implications of trade liberalization under imperfect competition. Economics Letters, 88(1), 27-31.

Hisali, E. (2012). Trade Policy Reform and international trade tax revenue in Uganda. Economic Modelling, 29(6), 2144-2154.

Honohan, P., \& Klingebiel, D. (2003). The fiscal cost implications of an accommodating approach to banking crises. Journal of Banking \& Finance, 27(8), 1539-1560.

Jha, P., \& Gozgor, G. (2019). Globalization and taxation: Theory and evidence. European Journal of Political Economy, 59, 296-315.

Kate, F., \& Milionis, P. (2019). Is capital taxation always harmful for economic growth? International Tax and Public Finance, 1-48. 
Li, X. L., Balcilar, M., Gupta, R., \& Chang, T. (2016). The causal relationship between economic policy uncertainty and stock returns in China and India: Evidence from a bootstrap rolling window approach. Emerging Markets Finance and Trade, 52(3), 674-689.

Lim, M., \& Goh, S. (2012). How Malaysia weathered the financial crisis: Policies and possible lessons in how to prevent the next crisis: Lessons from country experiences of the global financial crisis. The North-South Institute, pp. 1-20.

Mahdavi, S. (2008). The level and composition of tax revenue in developing countries: Evidence from unbalanced panel data. International Review of Economics and Finance, 17(4), 607617.

Maki, D. (2012). Tests for cointegration allowing for an unknown number of breaks. Economic Modelling, 29(5), 2011-2015.

Marrero, G. A., \& Novales, A. (2011). Growth, income taxes and consumption aspirations. Economics Letters, 113(3), 221-224.

Mujumdar, S. (2004). Revenue implications of trade liberalization under imperfect competition. Economics Letters, 82(1), 83-89.

Nwosa, P. I., Saibu, M. O., \& Fakunle, O. O. (2012). The effect of trade liberalization on trade tax revenue in Nigeria. African Economic and Business Review, 10(2), 28-43.

Nyblom, J. (1989). Testing for the constancy of parameters over time. Journal of the American Statistical Association, 84(405), 223-230.

Ojede, A., \& Yamarik, S. (2012). Tax policy and state economic growth: The long-run and shortrun of it. Economics Letters, 116(2), 161-165.

Perron, P. (1997). Further evidence on breaking trend functions in macroeconomic variables. Journal of Econometric, 80(2), 355-385.

Pesaran, M. H., Shin, Y., \& Smith, R. J. (2001). Bounds testing approaches to the analysis of level relationship. Journal of Applied Econometrics, 16(3), 289-326.

Samargandi, N., Fidrmuc, J., \& Ghosh, S. (2015). Is the relationship between financial development and economic growth monotonic? Evidence from sample of middle-income countries. World Development, 68, 66-81.

Shukur, G., \& Mantalos, P. (2000). A Simple Investigation of the Granger Causality in IntegratedCointegrated VAR System. Sweden: Working Paper University of Lund.

Tagkalakis, A. (2011). Fiscal policy and financial market movements. Journal of Banking \& Finance, 35(1), 231-251.

Tagkalakis, A. (2013). The effects of financial crisis on fiscal positions. European Journal of Political Economy, 29, 197-213.

Uddin, G. S., Sjo, B., \& Shahbaz, M. (2013). The causal nexus between financial development and economic growth in Kenya. Economic Modelling, 35, 701-707.

World Bank. (2018). World Development Indicators. Retrieved from http://data.worldbank.org/data-catalog/world-development-indicators.

Yong, L. Y., Yahya, M. H., Amin Noordin, B. A., \& Selamat, A. I. (2019). The effect of goods and services tax (GST) imposition on stock market overreaction and trading volume in Malaysia and Australia. Jurnal Pengurusan, 55, 73-84.

Zhixin, Z., \& Ya, L. (2011). The impact of carbon tax on economic growth in China. Energy Procedia, 5, 1757-1761. 


\section{APPENDIX}

Figure 2: Rolling Window Estimates of Tax and Trade

a) Bootstrap p-values of the LR test statistic, testing the null hypothesis Tax does not Granger cause Trade

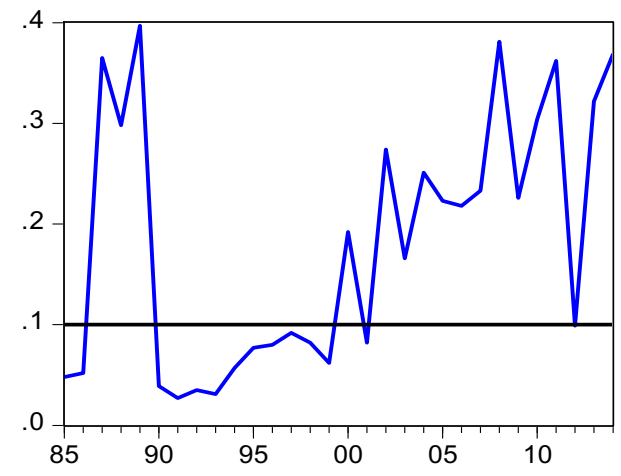

b) Bootstrap p-values of the LR test statistics, testing the null hypothesis Trade does not Granger cause Tax

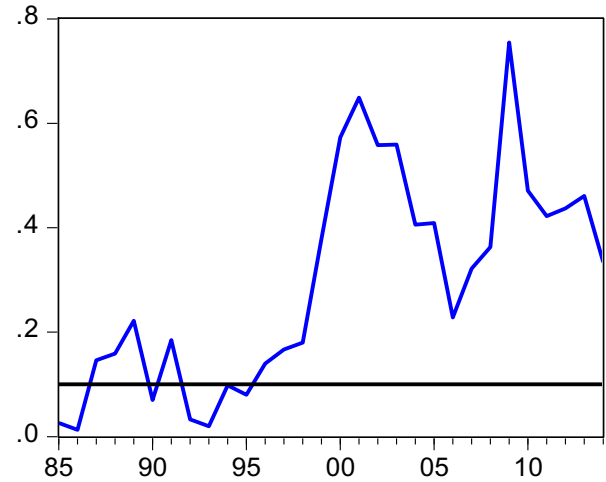

c) Bootstrap estimate of sum of the rolling coefficients for the impact of Tax on Trade

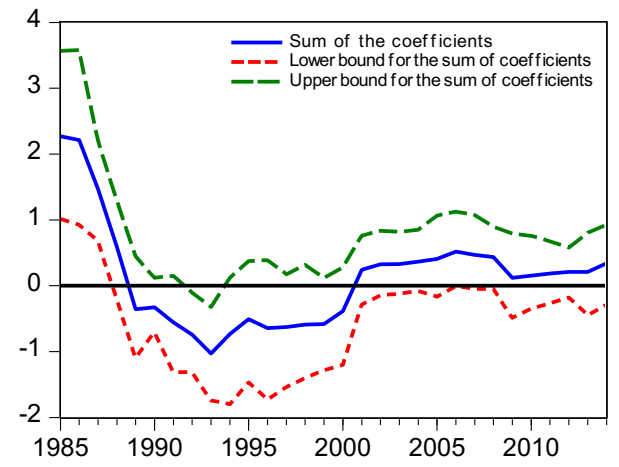

d) Bootstrap estimate of sum of the rolling coefficients for the impact of Trade on Tax

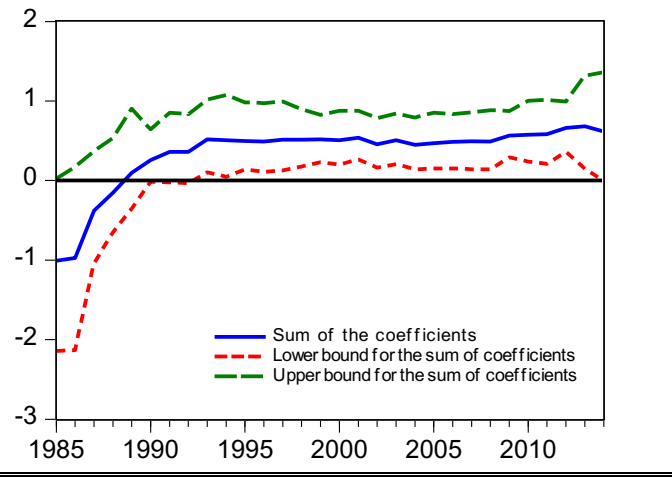


Figure 3: Rolling Window Estimates of Tax and $F D$

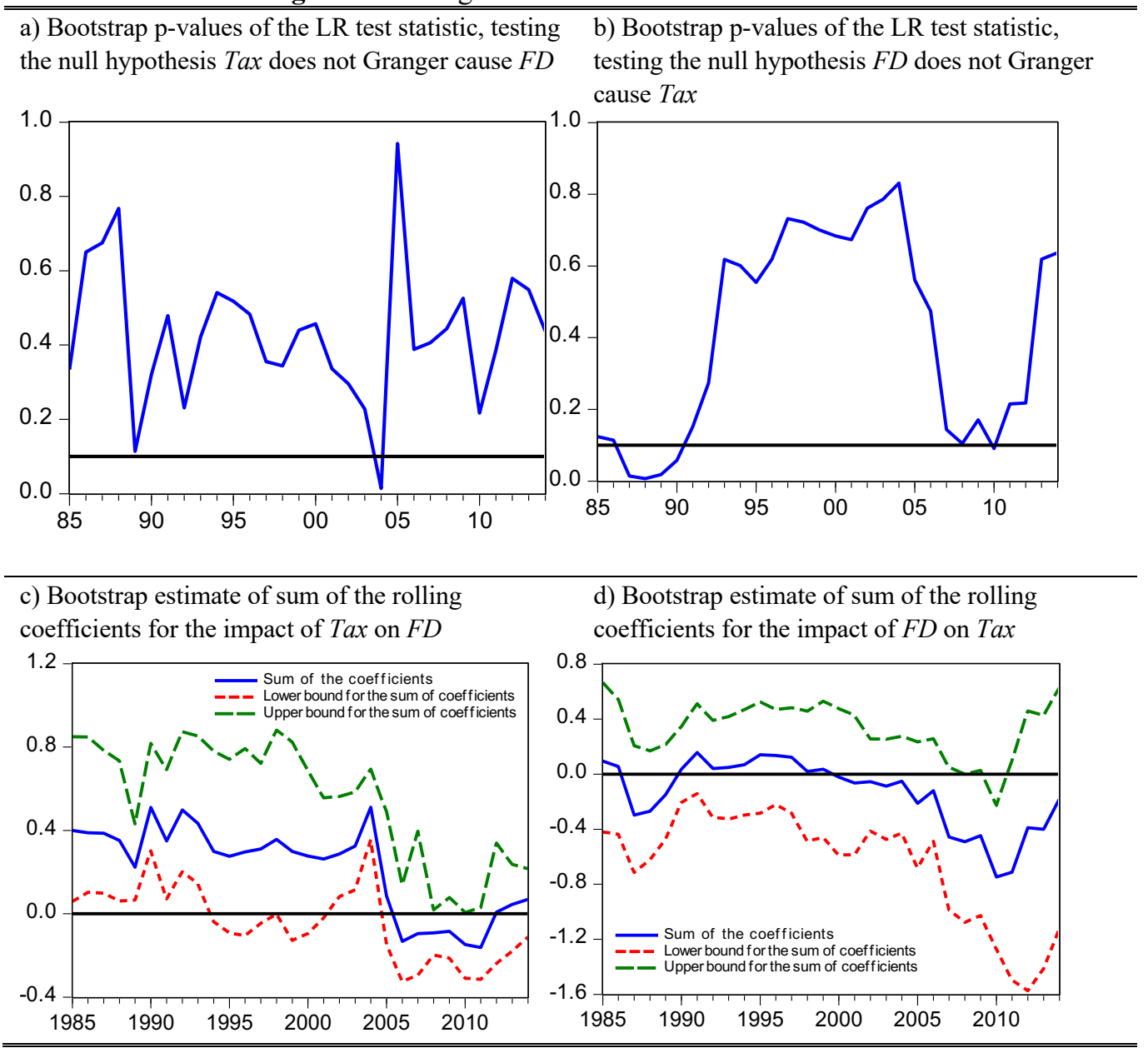


Figure 4: Rolling Window Estimates of Tax and GDP

a) Bootstrap p-values of the LR test statistic testing the null hypothesis Tax does not Granger cause

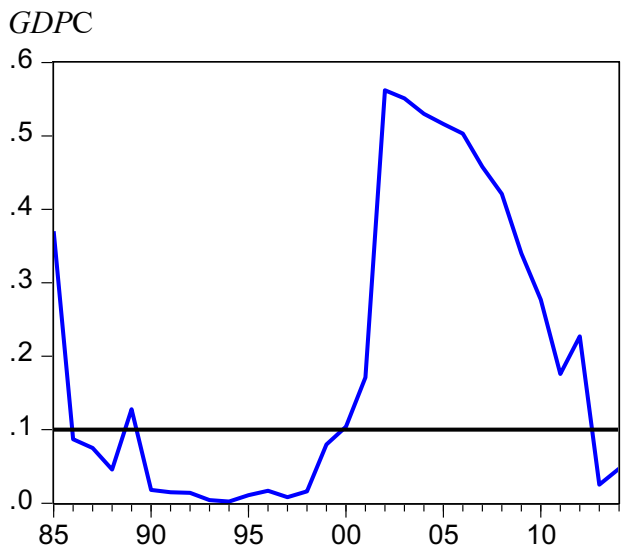

b) Bootstrap p-values of the LR test statistic testing the null hypothesis GDPC does not Granger cause

$\operatorname{Tax}$

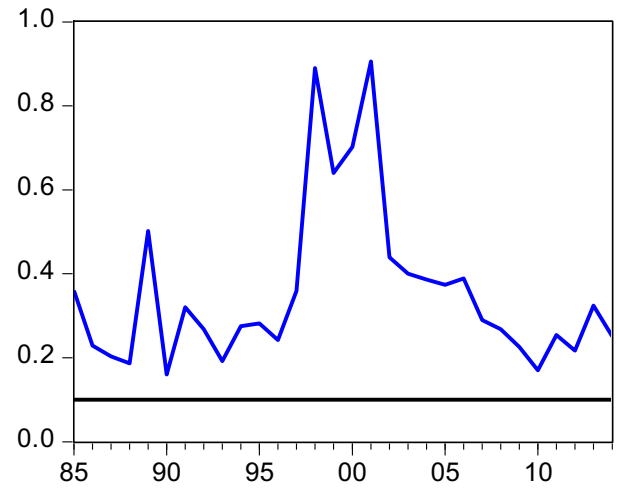

c) Bootstrap estimate of sum of the rolling coefficients for the impact of Tax on GDPC

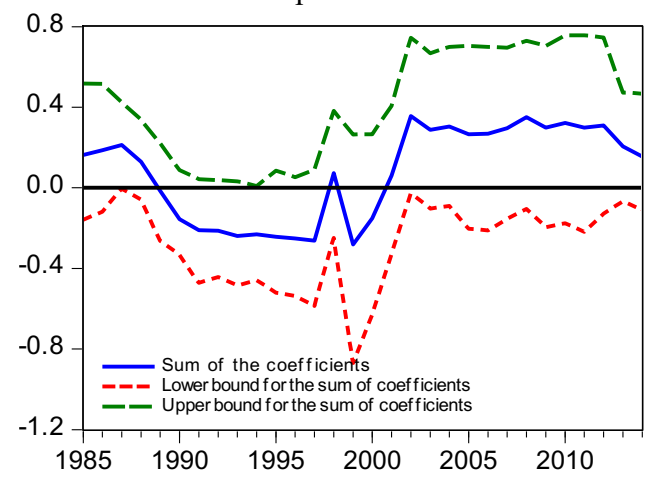

d) Bootstrap estimate of sum of the rolling coefficients for the impact of GDPC on Tax

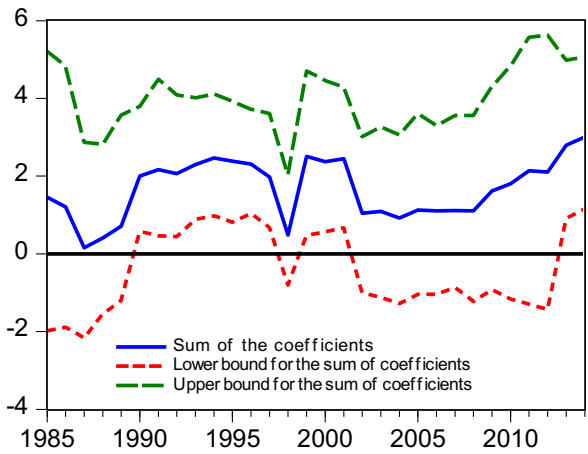

